\title{
Is Hydra an Alarm Clock?
}

\author{
Shostak Stanley* \\ Biology Department at the University of Pittsburgh, Pittsburgh PA, USA
}

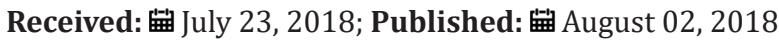

*Corresponding author: Shostak Stanley, Biology Department at the University of Pittsburgh, Pittsburgh PA, USA

Keywords: Feeding; Illumination; Temperature; Equilibrium Condition; Bud Module; Breaking Event; Incipient Bud; Tentacles; Repositories

\section{Introduction}

Recently, I've wondered what the results of old experiments would look like today. My abiding question throughout the years has been, "How do hydras parcel out parental cells and mould them into buds?" I was asking the question back in 1979 when I gave a talk at the unforgettable $4^{\text {th }}$ International Coelenterate Conference hosted by Pierre and Ruth Tardent at beautiful Interlaken [1]. The talk was entitled, "Can Hydra count?" Specifically, what accounts for hydras producing replicas of itself as buds with remarkably constant numbers of tentacles? At the time I was unsure of the answer, but I was confident it was the right question. Since then I've grown confident about the answers: "Yes!" Hydra counts buds by filling bud modules with parental cells, and "Yes," incipient buds have definitive numbers of tentacle rudiments. But now I wonder if I asked the right question? I think I might better have asked: "Is Hydra an alarm clock?" Are hydras set to go off with determinate buds? That's the question I'm addressing today with new and old data [2].

\section{Polarity and Budding}

Shown here is a representative Hydra viridis at equilibrium from a 1967 paper. As you see, budding is inherently polarized since it takes place in a distal to proximal direction. In this representative H. viridis, buds are displaced basally as they progress from early to later stages of development [3]. Not only is the incipient bud formed in the distal part of the budding region with distal parental cells, but buds pick up progressively more basal parental cells while moving basally. The addition of parental cells onto the elongating bud replicates the polarity of the parent [4]. Polarity is also revealed in differences between the role of cell division in the morphogenesis of the bud's apical and basal structures. Starved animals will continue to initiate the formation of buds after growth ceases, but buds of hydras treated with inhibitors of cell division (i.e. Colcemid, colchicine, and others) and failing to incorporate tritiated thymidine do not form feet and detach [5]. Treated hydras retain buds (i.e. pseudo-colonial hydras) have two (or more) heads. While head formation is independent of concurrent cell division, the differentiation of a bud's foot and detachment from the parent requires concurrent cell division (Figure 1).

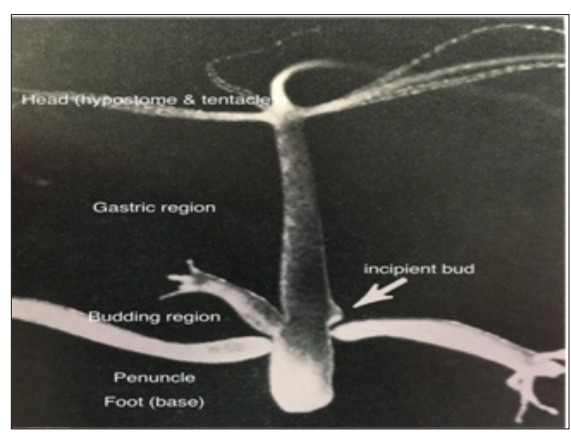

Figure 1 : PP1 Hydra (labeled).

\section{Variability of Tentacle and Cell Numbers in Buds}

Under optimal laboratory conditions of feeding, illumination, and temperature, freshly detached buds of $H$. viridis grow for a week, commence budding, and approach their maximum size length, diameter, and surface area [6]. In the second week these hydras reach their equilibrium condition, maintaining their body size thereafter while forming and detaching buds. The rate of cell division continues unabated at equilibrium, and cell density and total cell number no longer increase [7]. Cell division continues, nevertheless, at the same rate it had in freshly detached buds and during the bud's initial growth period. Cells produced at equilibrium are excess but not detritus [8]. They are funnelled into buds. Richard Campbell calculated, that in H. littoralis, under optimal laboratory conditions, $85-86 \%$ of hydra's structural cells produced throughout its gastric, budding, and upper peduncle regions are funnelled into buds in the budding region. The remaining 14-15\% 
of the structural cells reside in the vicinities of hydra's tentacles and foot where cells differentiate and are lost by attrition [9]. These numbers are similar in $H$. viridis. At equilibrium, therefore, the vast majority of cells produced on the parent's body are "excess" taken up on buds $\square$ i.e., buds are repositories of excess cells adapted to asexual reproduction [10-15].

\section{Buds, Budding, and Tentacle Numbers as Functions of Temperature and Feeding Schedule}

The formation of these early buds is not a passive consequence of parental cell movement to the budding region, and hydra's body wall does not descend on the budding region en masse. Rather than a glue holding the two epithelial layers together, the parental mesoglea is a substratum for cell movement [16]. The production of new mesoglea components takes place exclusively "at sites of tissue evagination. The mesoglea is dramatically remodelled and epithelial cells move relative to the mesoglea" Aufschnaiter et al. $[1,17]$.

\section{Experimental Approaches}

Given, therefore, that buds are filled with excess parental cells moving to the budding region, members of my lab and I set out to ascertain the parameters of cell movement by rearing hydras on different feeding schedules and at different temperatures [18-22] (Table 1).

Table 1: PP3 Buds, budding, tentacle numbers, temperature and feeding schedule.

\begin{tabular}{|c|c|c|c|c|}
\hline Number Days Fed* & 1 & 2 & 3 & 4 \\
\hline Number tentacles/bud & $6.32 \pm 0.26$ & $6.42 \pm 0.19$ & $6.53 \pm 0.26$ & $6.92 \pm 0.32$ \\
\hline Number digestive cells/bud & $4614 \pm 83$ & $6508 \pm 153$ & $9284 \pm 1416$ & $12278 \pm 3015$ \\
\hline Temperatures** & $18^{\circ} \mathrm{C}$ & $23^{\circ} \mathrm{C}$ & $28^{\circ} \mathrm{C}$ & $2.54 \pm 0.01$ \\
\hline Number buds/parent & $2.97 \pm 0.06$ & $2.78 \pm 0.06$ & $1.88 \pm 0.14$ & $1.01 \pm 0.02$ \\
\hline Number buds initiated/day & $0.68 \pm 0.04$ & $1.28 \pm 0.06$ & $1.01 \pm 0.14$ & $2.89 \pm 0.12$ \\
\hline Duration bud Development & $4.73 \pm 0.22$ & $2.04 \pm 0.12$ & $6.02 \pm 0.17$ & $6.40 \pm 0.16$ \\
\hline Number tentacles/bud & $6.68 \pm 0.16$ & $6.50 \pm 0.16$ & \\
\hline \multicolumn{2}{|r|}{ Shostaks, 1979. Digestive cell and tentacle number in freshly detached buds of Hydra viridis. Internet. J. Invert. Repo. 1: 167-178. } \\
\hline \multicolumn{2}{|r|}{ Shostak s, 1981. Variation in Hydra's tentacle numbers as a function of temperature. Internet. J. Invert. Repo. 3: 321-331. } \\
\hline
\end{tabular}

\section{Feeding schedule}

How then does feeding schedule influence the size of the structural cell population and tentacle number on freshly detached buds?" In my lab, $H$. viridis (in illuminated incubators at $21^{\circ} \mathrm{C}$ ) fed fresh brine shrimp larvae regularly once a day for five days a week reached and maintained equilibrium indefinitely [23-28]. We began our experiments, therefore, feeding our hydras one to four days a week. Here (Table 1), you see, as you would have expected (top data lower row), that the populations of digestive cells in newly detached buds were consistently and significantly larger on animals fed on increasing numbers of consecutive days [29-31]. However, the number of tentacles on buds did not differ significantly $(0.10$ $<\mathrm{P}<0.25$ ). Therefore, the larger number of cells (bottom row) did not significantly impact the number of tentacles (upper row) [32].

\section{Temperature}

Some of the effects oftemperatures on budding were already well known [33]. Conspicuously, hydras cultured at lower temperatures are larger, while hydras cultured at higher temperatures produce more buds than those cultured at lower temperatures. Moreover, hydras produce more buds when shifted from lower to higher temperatures [34]. Our objective was to measure the quantitative effects of temperature on specific parameters of budding. We fed $H$. viridis five days a week and placed the animals in illuminated incubators at different temperatures $\square 17-18^{\circ} \mathrm{C}, 22-23^{\circ} \mathrm{C}$, and 27 $28^{\circ} \mathrm{C}$. Beginning at the very bottom of the chart you see that hydras cultured at lower temperatures produced buds with significantly greater numbers of tentacles than hydras reared at higher temperatures [35]. The number of tentacles on buds produced by hydras maintained at different temperatures differed significantly (bottom row lower data). Presumably, animals kept at lower temperatures would not have grown at faster rates than animals kept at higher temperatures. The larger number of tentacles on animals maintained at the lower temperature, therefore, could not have been caused by faster growth [36]. Down the table $\square$ the duration of bud development in days, the number of buds initiated per day, and the number of buds present on parents $\square$ all differed significantly among hydras cultured at $18^{\circ} \mathrm{C}, 23^{\circ} \mathrm{C}$, and $28^{\circ} \mathrm{C}$.

The greater number of buds present on parents at cooler temperatures (first row) is consistent with buds taking longer to develop at cooler temperatures (third row down) [37]. Conceivably, fewer buds are initiated per day at colder temperatures (second row down) because these parents are growing slower or accumulating larger bud primordia. Slower growth would also be consistent with the buds taking longer to develop at lower temperatures (i.e. duration of bud development) but would not explain the significant difference in tentacle number on buds of hydras raised at different temperatures (bottom row upper data). The smaller number of buds initiated per day (lower data second row) at $18^{\circ} \mathrm{C}$ is consistent with more slowly growing parents taking longer to accumulate enough cells to initiate a bud. The greater number of tentacles on buds produced at lower temperatures (bottom row lower data) suggests that larger bud modules might take longer to fill on parents at lower temperatures [38]. 


\section{Bud Modules}

All of which brings me to "the possibility that buds are initiated... [from] a specific number of cells" [29] a definitive bud module (a.k.a. "circle" or "placode") formed at the juncture of the gastric and budding region. The formation of such a module would be a symmetry breaking event in the parent's body wall that is resolved by the eruption of an incipient bud and the perpendicular outgrowth of a bud primordium. Were we to assume, therefore, that there is such a thing as a bud module, its size would seem to be determined by temperature (larger at lower temperatures), while the rate at which modules are filled would be a function of the rate of parental cell division (faster at higher temperatures) [39]. The size of freshly detached buds (i.e. in terms of cell population and number of tentacles) would be largely a function of the size of the original bud module, and only marginally a function of the bud's final cell number [40].

\section{Conclusion}

Returning to my original question, "Is hydra an alarm clock set to go off?" the answer is definitively positive. A hydra sets off a bud when excess parental cells migrate into the budding region to fill a bud module [41]. The module then runs through a determinate sequence of developmental events as it moves proximally and develops basal features. The number of tentacles developing on buds is determined by the initial size of the module, which is constrained by temperature [42]. The rate of bud development is constrained by nutrition [43]. The formation of the bud's foot and detachment is determined by cell division in peduncle cells. I see that my time is up, so let me thank you for your attention. I hope we have time for some questions [44].

\section{References}

1. Aufschnaiter R, EA Zamir, CD Little, S Özbek, S Münder et al. (2011) In vivo imaging of basement membrane movement: ECM patterning shapes Hydra polyps. J Cell Sci 124(23): 4027-4038.

2. Aufschnaiter R, R Wedlich Söldner, X Zhang, B Hobmayer (2017) Apical and basal epitheliomuscular F-actin dynamics during Hydra bud evagination. Biology Open 6(8): 1137-1148.

3. Bisbee JW (1973) Size determination in Hydra: The roles of growth and budding. J Exp Morphol 30: 1-20.

4. Bode H, S Berking, CN David, A Gierer, H Schaller et al. (1973) Quantitative analysis of cell types during growth and morphogenesis in Hydra. Wilhelm Roux' Arch. Entwicklungsmech. Org 171(4): 269-81.

5. Brien P, M Renier Decoen (1949) La croissance, la blastogénèse, l'ovogénèse chez Hydra fusca (Pakkas). Bull Biol Fracnce et Belg 83: 293-396.

6. Brien P, M Renier Decoen (1955) La signification des cellules interstitielles des Hydres d'eau douce et le problème dela reserve embryonnaire. Bull Biol Fr Belg 89: 258-325.

7. Burnett AL (1961) The growth process in Hydra. J Exp Zool 146: 21-84.

8. Burnett AL, RE Hausman (1969) Mesoglea of Hydra. 2. Possible role in morphogenesis. J Exp Zool 171: 15-24.

9. Campbell RD (1965) Growth and tissue renewal patterns in Hydra littoralis. Thesis, The Rockefeller Institute.

10. Campbell RD (1967) Tissue dynamics of steady state growth in Hydra littoralis. I. Patterns of cell division. Develop Biol 15(5): 487-502.
11. Campbell RD (1967) b Tissue dynamics of steady state growth in Hydra littoralis. II. Patterns of tissue movement. J Morphol 121(1): 19-28.

12. Campbell RD (1967) c Tissue dynamics of steady state growth in Hydra littoralis. III. Behavior of specific cell types during tissue movement. J Exp Zool 164: 379-392.

13. Campbell RD (1974) Cell movement in Hydra. Amer Zool 14(2): 523 535.

14. Campbell RD (1980) The role of muscle processes in Hydra morphogenesis in P \& R Tardent (eds) Developmental and Cellular Biology of Coelenterates. Amsterdam: Elsevier/North-Holland Biomedical Press Pp: 421-428.

15. Clarkson SG, L Wolpert (1967) Bud morphogenesis in Hydra. Nature 214(5090): 780-783.

16. Diel FA, AL Burnett (1965) The role of interstitial cells in the maintenance of Hydra. II. Budding J Exp Zool 158: 283-298.

17. Liu TT, JT Chang (1946) Number of tentacles in Hydra vulgaris as a genetic character. Nature 157: 728.

18. Otto JJ, RD Campbell (1977) Tissue economics of hydra: regulation of cell cycle, animal size and development by controlled feeding rates. J Cell Sci 28: 117-132.

19. Otto JJ, J Dunne, P Wirth, RD Campbell (1976) Tissue behavior during budding in Hydra attenuate. Am Zool 16: 186.

20. Park HD, AB Ortmeyer (1973) Growth and differentiation in Hydra: II. The effect of temperature on budding in Hydra littoralis. J Exp Zool 179(2): 283-288.

21. Park HD, CL Greenblatt, CRT Mattern, CR Meril (1967) Some relationships between Chlorohydra, its symbionts and some other chlorophyllous forms. J Exp Zool 164: 141-62.

22. Parke HH (1900) Variation and regulation of abnormalities in hydra. Wilhelm Roux' Arch. Entwicklungsmech. Org 10: 692-710.

23. Sanyal S (1966) Bud determination in Hydra. Indian J Exp Biol 4(2): 8892.

24. Shimizu H, X Zhang, J Zhang, A Leontovich, K Fei et al. (2002) Epithelial morphogenesis in hydra requires de novo expression of extracellular matrix components and matrix metalloproteinases. Develop 129(6): 1521-1532.

25. Shostak S (1967) Bud movement in Hydra. Science 155(3769): 15671568.

26. Shostak S (1968) Growth in Hydra viridis. J Exp Zool 169(4): 431-446.

27. Shostak S (1974) The complexity of Hydra: Homeostasis, morphogenesis, control and integration. Quart Rev Biol 49(4): 287-310.

28. Shostak S (1979) Digestive cell and tentacle number in freshly detached buds of Hydra viridis. Internat, J Invert Repro 1: 167-178.

29. Shostak S (1980) “Can Hydra count?" in P. \& R. Tardent (eds.) Development and Cellular Biology of Coelenterates. Amsterdam: Elsevier/North-Holland Biomedical Press Pp: 231-236.

30. Shostak S (1981) Variation in the hydra's tentacle numbers as a function of temperature. Int J Invert Reprod 3: 321-331.

31. Shostak S (1982) Structural cell number and regeneration in Chlorohydra viridissima. J Exp Zool 222(1): 69-71.

32. Shostak S (2005) "Cnidaria" in Reproductive Biology of Invertebrates Volume VI, Part A: Asexual Propagation and Reproductive Strategies, K.G. and R.G. Adiyodi (eds). New Delhi, India: Oxford \& IBH Publishing Pp: 45-105.

33. Shostak S (2017) Hydra's complexity: Budding and cancer. Trends Devel Biol 10: 31-39.

34. Shostak S, M Globus (1966) Migration of epithelia-muscular cells in Hydra. Nature 210: 218-219. 


\section{Shostak S, Kankel (1967)}

36. Shostak S, RV Tammariello (1969) "Supernumerary heads in Hydra viridis" in C.J. Dawe and J.C. Harshbarger (eds.) A Symposium on Neoplasms and Related Disorder or Invertebrate and Lower Vertebrate Animals. Monograph National Cancer Institute 31: 739-750.

37. Shostak S, JA Adams (1975) Morphogenetic gradients in multiplegraft Hydra viridis. I: The effects of Colcemid and colchicine. J Exp Zool 192(1): 43-56.

38. Shostak S, NG Patel, AL Burnett (1965) The role of mesoglea in mass cell movement in Hydra. Develop. Biol 112: 434-450.

39. Shostak S, JW Bisbee, C Ashkin, RV Tammariello (1968) Budding in Hydra viridis. J Exp Zool 169: 423-430.

\section{ISSN: 2574-1241}

DOI: 10.26717/BJSTR.2018.07.001521

Shostak Stanley. Biomed J Sci \& Tech Res

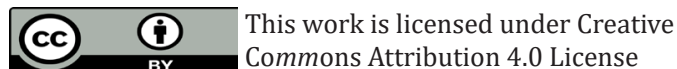

Submission Link: https://biomedres.us/submit-manuscript.php
40. Shostak S, D Medic, FA Sproull, CC Jones (1978) Tentacle number in culture Hydra viridis. Biol Bull 155: 220-234.

41. Stiven AE (1962) The effect of temperature and feeding on the intrinsic rate of increase of three species of Hydra. Ecology 43(2): 325-328.

42. Stiven AE (1965) The relationship between size, budding rate and growth efficiency in three species of Hydra. Res Popul Ecol Kyoto 7(1): $1-15$.

43. Tannreuther GW (1909) Budding in Hydra. Biol Bull 16: 210-214.

44. Webster G, S Hamilton (1972) Budding in Hydra: The role of cell multiplication and cell movement in bud initiation. J Embrol exp Morphol 27(2): 301-316.

Assets of Publishing with us
BIOMEDICAL
RESEARCHES $\quad \begin{aligned} & \text { Global archiving of articles } \\ & \text { - Immediate, unrestricted online access }\end{aligned}$

